\title{
Towards a Philosophy of the Mobile Information Society
}

Kristóf Nyíri, Budapest

\section{The Rise of Mobile Studies}

This introductory section of my present paper is a kind of report on the ongoing social science research programme I am directing: the project "Communications in the 21st Century", launched in January 2001, conducted jointly by T-Mobile Hungary (until 2004 Westel Mobile) and the Hungarian Academy of Sciences. In the framework of the project a number of international conferences were held, on the basis of which altogether eleven volumes - four Hungarian, one German, and six English - have been published. I will first give a very brief summary of these volumes, and then provide a more detailed description of some of the main results we arrived at.

The eleven volumes are witness to the history of the mobile phone between 2001 and 2007, no doubt the most dynamic aspect of the recent history of technological and social transformation. But most of all they amount to a first laying of the foundations for, and at the same time the awakening to consciousness and self-reflection of, a young discipline: the social science of mobile communication. Initially, research on problems pertaining to the mobile arose as an interdisciplinary task. From the interdisciplinary research, each of the participating disciplines profited, being forced to take account, on the level of theory, of the new medium which by now has come to constitute their main communicational environment. As a consequence of this taking account of the new realities, by 2005 a transformation was occurring which today has clearly become irreversible: the internal adaptation of the social sciences to the world of mobile communications. At the same time, an autonomous line of research emerged, based on a set of wellestablished paradigms of its own: the social science of mobile communication, Mobile Studies. Both aspects of this juncture in the history of science are represented in Nyíri (2007a, 2007b), which on the one hand takes stock of the paradigmatic results of mobile studies, and on the other hand highlights some new perspectives of the social sciences becoming aware of their mobile environment. 
Our first two Hungarian collections (Nyíri 2001a, 2001b) on the one hand gave an initial inventory of the pertinent research problems and conceptual resources, and on the other hand, by way of drawing, as it were, a sketch of the mobile horizons of the future, formulated the following theses/hypotheses: 1. Mobile communication and physical mobility mutually reinforce each other-the internet and mobile telephony ultimately result in more, not less, travel and personal encounters. 2. Since knowledge is information embedded in context, and mobile communication is markedly situation-dependent and thus context-creating, the mobile information society is likely to be a society of knowledge, not of mere information. 3. Mobile, interactive, multimedia communication amounts to a return, on a higher level, to primordial, less-alienated forms of communication. 4. Mobile communication induces changes in human cognitive faculties. 5. The nature of political communication becomes transformed. 6 . The nature of scientific communication becomes transformed.

The third Hungarian-language collection (Nyíri 2002b) appeared as an enlarged variant of the parallel German and English volumes (Nyíri 2002a, 2003a). This collection discussed in depth the notion of the information society as a knowledge community; among its chapters were Robin Dunbar's essay on gossip as a mechanism for maintaining community cohesion, and a definitive study on m-politics by Miklós Sükösd and Endre Dányi. ${ }^{2}$

Of the five other English-language volumes following upon (Nyíri 2003a), in the same year a further two appeared: (Nyíri 2003b), which played a pioneering role in the social scientific exposition of the notion of "m-learning", a notion that today is very much in the centre of educational theory; and (Nyíri 2003c), presenting the mobile phone as the very answer to the communicational challenges of a decentralized global mass society. In the collection (Nyíri 2005) we strove to demonstrate that the mobile phone is not just an instrument for enabling global contacts, but also a means to maintain local bonds, organizing the life of small regions and small territories. (Nyíri 2006a) once more turned to the issue of m-learning, this time on a markedly philosophical level. It told of the revolution in epistemology, in particular about the revolution in educational theory; of our mobile companion as part of our mind; of the return of collective thinking; and of the development of the world of non-formal learning. To (Nyíri 2007a) I have referred to above.

Besides the literature mentioned in note 1 above, I would here like to single out four further excellent monographs on the topic of mobile communication: Ling (2004), from which I received a major impetus for my Kirchberg paper (Nyíri 2006b); Levinson (2004); Goggin (2006); and, last but not 
least, Castells et al. (2007). Between 1996 and 1998, Manuel Castells published his famous trilogy The Information Age (to which I will have occasion to come back presently) taking some 1400 pages to reach the conclusion that information and communication technologies were deepening, rather than closing, the gap between the rich and the poor. As he would characteristically put it in his unfathomable left-wing idiom: ICTs were instrumental in supplanting the "space of places" by a "space of flows". In 1999, I put a vicious review of the work onto the web. ${ }^{3}$ In the following years I have come to regret the viciousness, but certainly not the critical stance, of the review. And it is with great satisfaction I note that, under the impact of the rise of the mobile phone, Castells himself has by today quite dramatically shifted his position. Castells et al. (2007), actually published in November 2006, fully recognizes the liberating effects of today's dominant ICT, namely mobile telephony.

\section{Knowledge Societies or Knowledge Communities?}

\section{1. The Notion of a Knowledge Society}

The new information and communication technologies herald the promise, and indeed have to a significant measure already brought about, changes which can be meaningfully discussed under the heading of knowledge societies. However, the term "knowledge societies" by now seems to have acquired two distinct, albeit related, meanings. In its first meaning it refers to the trend classically analyzed by Bell (1973). Bell's central term is "postindustrial society", but he also uses the terms "knowledgeable society" (Bell 1973, 263) and „knowledge society". The term "knowledge society" first occurs on p. 212 of the book. As Bell here writes:

Technology is one axis of the post-industrial society; the other axis is knowledge as a fundamental resource. Knowledge and technology are embodied in social institutions and represented by persons. In short, we can talk of a knowledge society. ... The postindustrial society, it is clear, is a knowledge society in a double sense: first, the sources of innovation are increasingly derivative from research and development (and more directly, there is a new relation between science and technology because of the centrality of theoretical knowledge); second, the weight of the society - measured by a larger 
proportion of Gross National Product and a larger share of employment—is increasingly in the knowledge field.

In a post-industrial society, knowledge and technology have become the central resources of society and economy. Perhaps it is the today oft-used circumlocution "knowledge-based society" that best expresses this state of affairs; and perhaps it is useful to stress, as especially Castells does, that what characterizes this society "is not the centrality of knowledge and information, but the application of such knowledge and information to knowledge generation and information processing/communication devices, in a cumulative feedback loop between innovation and the uses of innovation" (Castells 1996, 32). To be sure, the expressions "knowledge society" or "knowledgebased society" are not ones Castells would use. His preferred terms are, on the one hand, the well-worn "information society", and, on the other, "informational society" - the latter a phrase of his own coinage. I have indicated above that the term "information society" is misleading-confounding, as it were, information and knowledge; while Castells' tormented neologism "informational society" is unhelpful at best. The term first occurs in Castells' early book The City and the Grassroots (Castells 1983). It is here that he introduces, in the course of a rather hair-splitting elucidation, the concept "informational mode of development". Modes of development, Castells stresses in the wake of Touraine, must be carefully distinguished from modes of production; the concept of a mode of development "refers to the particular form in which labour, matter, and energy are combined in work to obtain the product. Work is certainly related to social (class) relationships, but, in addition to the way through which the surplus is appropriated, it is also important to understand how the surplus is increased." There are two types of mode of development, Castells here points out, the industrial and the informational, and then goes on to give a slightly confused explanation: "For the informational mode of production, productivity is based on knowledge... Informationalism is orientated towards technological development, that is, towards the accumulation of knowledge" (Castells 1983, 307). In his deservedly famous The Informational City - the book in which Castells, for the first and the last time, can actually bring himself to believe that the new information technologies might have a politically liberating potential- there occurs the felicitous formulation "what is specific to the informational mode of development is that here knowledge intervenes upon knowledge itself to generate higher productivity" (Castells 1989, 10), only to give way, in The Information Age, again, to a rather less transparent "analytical distinction" between 
the notions of "information society" and "informational society", with similar implications for information/informational economy. The term information society emphasizes the role of information in society. But ... information, in its broadest sense, e.g. as communication of knowledge, has been critical in all societies, including medieval Europe which was culturally structured, and to some extent unified, around scholasticism, that is, by and large an intellectual framework... In contrast, the term informational indicates the attribute of a specific form of social organization in which information generation, processing, and transmission become the fundamental sources of productivity and power, because of new technological conditions emerging in this historical period (Castells 1996, 21).

To my review of Castells' work I have referred above, in section 1.

In its second meaning the term "knowledge society" is connected with the idea of universal access to knowledge, emphasizing that while such access is becoming increasingly attainable today, it was never a possibility in earlier ages. In a trivial sense, all societies are knowledge-based; however, much of the knowledge both in traditional societies and all through modernity was possessed by a minority, and much of that knowledge was not knowledge at all, but rather myth, superstition, lethal error or, at best, spurious learning. It does a disservice to progress to deny that we are today in fact witnessing a historical turning-point, and that past societies were ignorance-based societies rather than knowledge-based societies.

\section{2. Information and Knowledge}

Echoing T. S. Eliot's famous lines from the early 1930s- "Where is the wisdom we have lost in knowledge? Where is the knowledge we have lost in information?"- John Naisbitt in his popular book Megatrends (Naisbitt 1982) bemoans the phenomenon that the world is "drowning in information, but is starved for knowledge". Naisbitt's formulation is taken up by Vartan Gregorian among many others, in an address given in $1992 .{ }^{4}$ Gregorian-at that time President of Brown University-there also refers to Carlos Fuentes as saying that "one of the greatest challenges facing modern society and contemporary civilization is how to transform information into knowledge". The conclusion Gregorian reaches is that today's educational institutions must be careful to "provide not just information, but its distillation, namely knowledge".

The notion that "information" is somehow inferior to "knowledge" is not of recent origin. Although the Latin word informare, meaning the action of 
forming matter, such as stone, wood, leather, etc., also took on the senses "to instruct", "to educate", "to form an idea"s_C Cicero's informare deos coniectura was explained as "imaginer en son esprit et conjecturer quels sont les dieux" by Robert Estienne in his Dictionarium Latinogallicum (1552)_ “informare" in Italian, "informer" in French, and "to inform" in English from the beginning had the connotation of conveying knowledge that is merely particular. Perhaps another Latin word, informis - meaning unshapen, formless - had, with its French and English derivatives ("informe", "inform"), a certain coincidental effect here. To have information amounted to knowing details, possibly unconnected. Hence the use of the word "information" in the contexts of criminal accusation, charge, legal process. John Locke, in his Essay Concerning Human Understanding (1690), might have thought that "information" had to do with "truth and real knowledge"; 6 however, what the OED refers to as the "prevailing mod. sense" of inform, namely "to impart knowledge of some particular fact or occurrence", or the Larousse phrase "informer quel-qu'un de quelque chose", indeed appear to capture the essentials of the concept.

Thus Roszak (1986) can correctly point out that in the days of his childhood, shortly before the outbreak of World War II, "information" was a dull word, referring to answers to concrete questions, having the form of names, numbers, dates, etc. With Shannon's and Weaver's technical concept of information, put forward in Shannon and Weaver (1949), and with the emergence of computers, it also became a misleading - and glorious - word. Attempts at clarification of course abound. Daniel Bell made such an attempt. As he wrote: "By information I mean data processing in the broadest sense; the storage, retrieval, and processing of data becomes the essential resource for all economic and social exchanges. ... By knowledge, I mean an organized set of statements of facts or ideas, presenting a reasoned judgment or an experimental result, which is transmitted to others through some communication medium in some systematic form" (Bell 1979, 168). Slightly less straightforward from the point of view of the present argument is Dretske's formula: "Roughly speaking, information is that commodity capable of yielding knowledge, and what information a signal carries is what we can learn from it" (Dretske 1981, 44).

Let me sum up the foregoing by saying that knowledge can be usefully regarded as information in context. Now it is a standard observation that information sought through mobile phones is, characteristically, locationspecific and situation-specific. It seems, then, that mobile communication tends to engender not just information, but information in context: that is, knowledge per se. 


\subsection{Communication and Community}

The early phase of the research project "Communications in the 21st Century" went under the title „The Mobile Information Society”, a phrase that has been current since 1999 or so. However, we have increasingly come to realize that it is a misleading phrase. For mobile communications point to a future which offers a wealth of knowledge, not just of information, and promise to re-establish, within the life of modern society, some of the features formerly enjoyed by genuine local communities. „Community” on the one hand, ,society" on the other, clearly differ in their connotations; and it was Tönnies who, towards the end of the nineteenth century, crystallized this difference into a conceptual contrast. As Tönnies sees it, community involves "real", "organic", continuous associations. While the members of societies "are essentially separated in spite of all connecting factors", the members of a community "remain essentially connected in spite of all separating factors". As Tönnies of course states, "community is old, society is new, as a phenomenon and as a name"; ${ }^{7}$ however, the striking observation in the recent literature on mobile telephony is that through constant communicative connectedness a kind of turning back to the living, personal interactions of earlier communities is brought about. Certainly this is the message of the formula "perpetual contact" in Katz and Aakhus (2002). The "socio-logic", indeed the "ontologies", of perpetual contact receive here (Katz and Aakhus 2002, 305-309) — not without a sidelong glance, incidentally, at Heidegger - an especially profound analysis in the closing essay by Katz and Aakhus, "Conclusion: Making Meaning of Mobiles - a Theory of $A p$ paratgeist". Writing about fixed-line telephone networks Claude S. Fischer had already in the early 1990s marshalled arguments against the view that "the telephone is yet another of modernity's blows against local Gemeinschaft, the close community" (Fischer 1994, 25).

Adhering to a fundamental idea of the German Romantic philosophy of language, Tönnies propounded the view that it is not individual consciousness, but rather communication within the commmunity, that is the agent of human thinking. "Mental life", writes Tönnies, "manifests itself through communication, that is through the effect on kindred beings through signs, especially words pronounced by the use of vocal organs. From this develops thinking, i.e., the communication to oneself through audible or inaudible speech" (Tönnies 1957, 107). In the introductory chapter "The Theory of Community" Tönnies emphasizes that language, which "by means of gestures and sounds, enables expressions", is not "a means and tool by which one makes oneself understood", but it is "itself the living understanding" 
(Tönnies 1957, 47). The same idea of course plays a major role also in Heidegger's views, for whom "understanding" and "being together" (Mitsein) are intrinsically related to each other. As he puts it in the famous $\S 34$ of $B e$ ing and Time, making assertions or giving information is just a special case of "communication". In its most general sense, communication is the relationship in which "being with one another is understandingly constituted"; "communication is never anything like a conveying of experiences ... from the interior of one subject into the interior of another" (Heidegger 1962, 205).

John Dewey already in 1915 formulated the thesis that social life is not just maintained by communication, but indeed constituted by it. As his oftquoted lines run:

Society not only continues to exist by transmission, $b y$ communication, but it may fairly be said to exist in transmission, in communication. There is more than a verbal tie between the words common, community, and communication. Men live in a community in virtue of the things they have in common; and communication is the way in which they come to possess things in common (Dewey 1915, 4).

Dewey's thesis is corroborated by contemporary research in evolutionary psychology. Robin Dunbar in his essay referred to above, in (Nyíri 2003a), propounds the view that language emerged in order to ensure social cohesion within primate groups at a stage where pre-verbal means of mutual attention had ceased to be effective due to growing group size. Language creates social cohesion and group identity; linguistic differences serve the isolating of groups from each other. With the increasing influence of literacy however there arises a functional disorder: written language appears as the "correct" one in contrast to the merely spoken dialects (Sándor 2003). The new technologies of communication - the rise of secondary orality, ${ }^{8}$ especially in the form of mobile telephony - now promise to heal that disorder.

Even the most cursory survey of the topic of communication and community would be one-sided without a reference to Deutsch (1953), a book it is imperative for contemporary philosophical research on communication to rediscover. Like Tönnies, Deutsch postulates a conceptual contrast between community and society, but in his case the dimension of communication plays a rather more explicit role than it did in Tönnies' work. Deutsch applies the notion of complementarity, originally a concept in communications theory, to the issues of social communication, and defines communities as characterized by patterns of communication that display a high level of complementarity between information conveyed through various channels 
(Deutsch 1953, $69 \mathrm{ff}$.). It is because of the drive to multimedia inherent in networked and mobile communication, and indeed because of the recent, quite overwhelming trend of telecommunications convergence-the amalgamation of the fixed-line phone, mobile telephony, internet access, and entertainment (IPTV) - that the approach of Deutsch today again appears as especially timely.

\section{The Network Individual}

In the age of telecommunications convergence, it appears to be warranted to speak of a new type of personality: the "network individual". The network individual is the person reintegrated, after centuries of relative isolation induced by the printing press, into the collective thinking of society-the individual whose mind is manifestly mediated, once again, by the minds of those forming his/her smaller or larger community. ${ }^{9}$ This mediation is indeed manifest: its patterns can be directly read off the displays of our electronic communications devices, of which the mobile phone has clearly become the central and most important. Also, there is a theoretical framework at our disposal in which those patterns can be conveniently classified and interpreted: Robin Dunbar's theory of the social brain.

According to this theory, ${ }^{10}$ language came about primarily as a tool of social intelligence. People mostly converse about others and about each other, gossip is a cohesive force. Dunbar established a co-variation between on the one hand the neocortex volume of primates, and on the other, various aspects of primate social behaviour, including social group size. If a primate species embarks on a path to living in a larger group so as to be able to more effectively solve its ecological problems, it has to develop a sufficiently large neocortex to provide capacities for the social information processing needed. Calculations show that with a neocortex of the size humans possess, we should live in groups of about 150 . And this in fact seems to be the case. "Although humans", writes Dunbar,

can obviously cope with very large urban environments and even nation-states, the number of people within those large population units with whom one can say that one has a direct personal relationship is very much smaller. Censuses of the population units of hunter-gatherers, the size of scientific sub-disciplines, the number of people to whom one sends Christmas cards and the number of people of whom one can ask a favour all turn out to be about 150 in number (Dunbar 2003, 58). 
Within this circle of 150 persons there is a series of smaller circles of individuals with whom we can maintain a relationship of a given degree of intensity. There is ample evidence to the effect that the number of persons we can have a particularly close connection with is limited to around $12-15$, and that there is an inner circle of about 5 persons with whom this relationship is especially strong. We have, in addition, grounds to believe that there may be a series of layers, with upper boundaries at around 35 and 80-100, each associated with a declining level of emotional closeness. Each of us as it were sits in the centre of a series of expanding circles of 5, 15, 35, 80 and 150 persons (Dunbar 2003, 59).

Let us now cast a glance upon our mobile phone. There are hundreds of telephone numbers stored (as well as, to say it parenthetically, thousands of e-mail addresses in our mailbox). The number of persons with whom in the course of time we have had SMS contacts, is again several hundreds-since quite often we have to send SMS messages even to strangers. Recall the formula, dismissive but not at all unusual, on the mobile answering device: "Please do not leave a message at this number. Send an SMS, or write an e-mail." However, we conduct regular SMS communication with a limited number of persons only-the figure is certainly below 35, and with most people even below 15. Finally, MMS messages will not be exchanged beyond one's circle of the most intimate friends - on the average with 5 persons at the utmost. As Döring et al. $(2006,198)$ put it: "The average number of people a person exchanges MMS messages with is estimated to be 2 to 5 , usually including his or her partner and close friends. This at the same time implies that MMS messages require the communication partners to share a high degree of contextual knowledge and are often incomprehensible to outsiders." 11

With the rise of Skype we have yet more access to a rich source of experiental data. How many people figure on one's "Skype Contacts" list? According to my informal survey, the list seldom contains more than 35 Skype-names - that is, the number of persons with whom we occasionally talk over the internet does not exceed the third Dunbarian circle. I have chosen the word "occasionally", since my impression is that the number of persons whom we regularly call using VoIP is nearer to 5 than to 15 . And the number 15 seems to indicate the approximate upper limit of the circle of persons with whom we maintain chat contact. I myself find it frustrating if my Skype contacts list refers to more than 15 persons, and again and again delete the Skype names of those to whom I do not have a really close relationship. This is, after all, a list I have continuously before my eyes, and it shows intimate details. I learn who is online when, who has not touched 
the computer for more than 5 minutes ("Away"), has deserted it for more than 20 Minutes ("Not Available") and who is online, but does not wish to be contacted ("Do Not Disturb"). Also, I see faces. Chat in its newer versions appears to be restricted, quite unequivocally, to the two innermost Dunbarian circles.

My list of approximately 15 persons of course contains names, too, which do not figure on the lists of my intimate chat partners - each of us inhabits the centre of different concentric circles. The friends of my friends are not necessarily my friends - and it is important that through my friends I should also be able to reach, when the need arises, strangers. We have arrived at Stanley Milgram's famous small-world phenomenon (Milgram 1967), also known as the ,six degrees of separation” pattern. In a way, I find it astonishing that Dunbar nowhere refers to Milgram, and indeed that research does practically not connect the two names with one another. For there is a rather obvious point where the results of the two meet: Milgram's circle of acquaintances known on a first-name basis is identical with the Dunbarian circle of 150. And we might assume that should the number of individuals one has a personal connection with overstep the limit of 150 - a development Dunbar holds impossible for cognitive reasons - the Milgram figure would in its turn decrease. Now the latter today is actually the case: a repeated experiment has yielded the number 4.6. As The Economist recently wrote: „Being able to keep in touch with a much wider range of people through technologies such as e-mail has brought everyone closer" (The Economist 2006, 4). Perhaps Dunbar does, after all, underestimate the effect of those most recent communications technologies upon our cognitive capacities. And with the ongoing convergence of telecommunications technologies, that effect is likely to become even more pronounced. In the global knowledge community on the rise, distances between people are characterized by ever smaller degrees of separation. 


\section{Endnotes}

${ }^{1}$ For some first responses to this challenge see Roesler (2000), and the outstanding volume Katz and Aakhus (2002); further Katz (1999), Kopomaa (2000), Brown, Green and Harper (2002). Rheingold (2002) is a useful compilation of quotes and interviews.

${ }^{2}$ Our Hungarian-language volumes are fully accessible, the German-language and English-language volumes partially accessible, via the www.socialscience.t-mobile.hu webpage.

${ }^{3}$ See http://www.hunfi.hu/nyiri/castells_rev.htm. Printed as (Nyíri 2004).

${ }^{4}$ See http://www.cni.org/docs/tsh/Keynote.html.

${ }^{5}$ Recall, also, the original meaning of the Greek words eidos or idea: "pattern", "visual form".

${ }^{6} \mathrm{Cf}$. book 3, chapter 10, sect. 34 .

${ }^{7}$ Compare Tönnies (1957, $33 \mathrm{ff}$. and 65). I had to modify the English translation at a number of points.

${ }^{8}$ The term "secondary orality" was coined by Walter J. Ong. As he put it: "with telephone, radio, television and various kinds of sound tape, electronic technology has brought us into the age of 'secondary orality'. This new orality has striking resemblances to the old in its participatory mystique, its fostering of a communal sense, its concentration on the present moment... But it is essentially a more deliberate and self-conscious orality, based permanently on the use of writing and print, which are essential for the manufacture and operation of the equipment and for its use as well. ... secondary orality generates a sense for groups immeasurably larger than those of primary oral culture" (Ong 1982, 136).

${ }^{9}$ I have begun using the term "network individual", for designating what I think is a new psychological type - and in a sense also the return to a primordial type of personality -in the early stages of the project "Communications in the 21st Century" (cf. http://www.socialscience.t-mobile.hu/2001_dec_konf/SUMMARIES.pdf, see also my preface in (Nyíri 2003c, 16). The network individual is not the uprooted, freefloating being as depicted by Barry Wellman. Wellman uses the term "networked individualism". His description: "People remain connected, but as individuals rather than being rooted in the home bases of work unit and household. Individuals switch rapidly between their social networks. Each person separately operates his networks to obtain information, collaboration, orders, support, sociability, and a sense of belonging" (Wellman 2002).

${ }^{10}$ See in particular (Dunbar 1996), as well as his essay in (Nyíri 2003a).

${ }^{11}$ For a philosophical interpretation of the issue of MMS, image, and context, see Kondor (2007). 


\section{Literature}

Bell, Daniel 1973 The Coming of Post-Industrial Society: A Venture in Social Forecasting, New York: Basic Books.

Bell, Daniel 1979 “The Social Framework of the Information Society”, in: M. L.

Dertouzos and Joel Moses (eds.), The Computer Age: A Twenty-Year View, Cambridge, MA: MIT Press, 163-211.

Brown, B., Green, N. and Harper, R. 2002 (eds.) Wireless World: Social and Interactional Aspects of the Mobile Age, London: Springer.

Castells, Manuel 1983 The City and the Grassroots: A Cross-Cultural Theory of Urban Social Movements, London: Edward Arnold.

Castells, Manuel 1989 The Informational City: Information Technology, Economic Restructuring, and the Urban-Regional Process, Oxford: Basil Blackwell.

Castells, Manuel 1996 The Information Age: Economy, Society and Culture, vol. 1: The Rise of the Network Society, Oxford: Blackwell.

Castells, Manuel et al. 2007 Mobile Communication and Society: A Global Perspective, Cambridge, MA: MIT Press.

Deutsch, Karl W. 1953 Nationalism and Social Communication: An Inquiry into the Foundations of Nationality, New York: John Wiley \& Sons.

Dewey, John 1915 Democracy and Education, New York: Macmillan Co.

Döring, Nicola, et al. 2006 "Contents, Forms and Functions of Interpersonal Pictorial Messages in Online and Mobile Communication", in: Kristóf Nyíri (ed.), Mobile Understanding: The Epistemology of Ubiquitous Communication, Vienna: Passagen Verlag.

Dretske, Fred I. 1981 Knowledge and the Flow of Information, Oxford: Basil Blackwell.

Dunbar, R. I. M. 1996 Grooming, Gossip, and the Evolution of Language, Cambridge, MA: Harvard University Press.

Dunbar, R. I. M. 2003 “Are There Cognitive Constraints on an E-World?", in: Kristóf Nyíri, Mobile Communication: Essays on Cognition and Community, Vienna: Passagen Verlag, 57-69.

Fischer, Claude S. 1992 America Calling: A Social History of the Telephone to 1940, Berkeley: University of California Press.

Goggin, Gerard 2006 Cell Phone Culture: Mobile Technology in Everyday Life, London: Routledge.

Heidegger, Martin 1962 Being and Time, transl. by John Macquarrie and Edward Robinson, Oxford: Basil Blackwell. Originally published as Sein und Zeit (1927).

Katz, James E. 1999 Connections: Social and Cultural Studies of the Telephone in American Life, New Brunswick, NJ: Transaction Publishers.

Katz, James E. and Aakhus, Mark 2002 (eds.) Perpetual Contact: Mobile Communica- 
tion, Private Talk, Public Performance, Cambridge: Cambridge University Press.

Kondor, Zsuzsanna 2007 "The Mobile Image: Experience on the Move", in: Kristóf Nyíri (ed.), Mobile Studies: Paradigms and Perspectives, Vienna: Passagen Verlag, 25-33.

Kopomaa, Timo 2000 The City in Your Pocket: Birth of the Mobile Information Society, Helsinki: Gaudeamus.

Levinson, Paul 2004 Cellphone: The Story of the World's Most Mobile Medium and How It Has Transformed Everything!, New York: Palgrave Macmillan.

Ling, Rich 2004 The Mobile Connection: The Cell Phone's Impact on Society, Amsterdam: Elsevier.

Milgram, Stanley 1967 “The Small-World Problem”, Psychology Today, 60-67.

Naisbitt, John, 1982 Megatrends, New York: Warner Books.

Nyíri, Kristóf 2001a (ed.) Mobil információs társadalom: Tanulmányok [The Mobile Information Society: Essays], Budapest: MTA Filozófiai Kutatóintézete.

Nyíri, Kristóf 2001b (ed.) A 21. századi kommunikáció új útjai: Tanulmányok [New Perspectives on 21st-Century Communications: Essays], Budapest: MTA Filozófiai Kutatóintézete.

Nyíri, Kristóf 2002a (ed.) Allzeit zuhanden: Gemeinschaft und Erkenntnis im Mobilzeitalter, Vienna: Passagen Verlag.

Nyíri, Kristóf 2002b (ed.) Mobilközösség-mobilmegismerés: Tanulmányok [Mobile Society—Mobile Cognition: Essays], Budapest: MTA Filozófiai Kutatóintézete.

Nyíri, Kristóf 2003a (ed.) Mobile Communication: Essays on Cognition and Community, Vienna: Passagen Verlag.

Nyíri, Kristóf 2003b (ed.) Mobile Learning: Essays on Philosophy, Psychology and Education, Vienna: Passagen Verlag, 2003.

Nyíri, Kristóf 2003c (ed.) Mobile Democracy: Essays on Society, Self and Politics, Vienna: Passagen Verlag.

Nyíri, Kristóf 2004 "Review of Castells, The Information Age", in: Frank Webster and Basil Dimitriou (eds.), Manuel Castells, London: SAGE, vol. III, 5-34.

Nyíri, Kristóf 2005 (ed.) A Sense of Place: The Global and the Local in Mobile Communication, Vienna: Passagen Verlag.

Nyíri, Kristóf 2006a (ed.) Mobile Understanding: The Epistemology of Ubiquitous Communication, Vienna: Passagen Verlag.

Nyíri, Kristóf 2006b "Time and Communication", in: F. Stadler and M. Stöltzner (eds.), Time and History / Zeit und Geschichte, Frankfurt/M.: ontos verlag, 301-316.

Nyíri, Kristóf 2007a (ed.) Mobile Studies: Paradigms and Perspectives, Vienna: Passagen Verlag.

Nyíri, Kristóf 2007b (ed.) Mobiltársadalomkutatás: Paradigmák - perspektivák [Mobile Studies: Paradigms and Perspectives], Budapest: MTA / T-Mobile.

Ong, Walter J. 1982 Orality and Literacy: The Technologizing of the Word, London: 
Methuen.

Rheingold, Howard 2002 Smart Mobs, Cambridge, MA: Perseus.

Roesler, Alexander 2000 "Das Telefon in der Philosophie: Sokrates, Heidegger, Derrida", in: Stefan Münker and Alexander Roesler (eds.), Telefonbuch: Beiträge zu einer Kulturgeschichte des Telefons, Frankfurt/M.: Suhrkamp, 142-160.

Roszak, Theodore, 1986 The Cult of Information, Cambridge: The Lutterworth Press.

Sándor, Klára 2003 "The Fall of Linguistic Aristocratism”, in: Kristóf Nyíri (ed.), Mobile Communication: Essays on Cognition and Community, Vienna: Passagen Verlag, 2003, 71-82.

Shannon, Claude E. and Weaver, Warren 1949 The Mathematical Theory of Communication, Urbana: The University of Illinois Press.

The Economist, 2006 Special survey The New Organisation, January 21 st.

Tönnies, Ferdinand 1957 Community and Society, East Lansing, MI: Michigan State University Press. Originally published as Gemeinschaft und Gesellschaft (1887).

Wellman, Barry 2002 "Little Boxes, Glocalization, and Networked Individualism", in: Makoto Tanabe, Peter van den Besselaar and Toru Ishida (eds.), Digital Cities II: Computational and Sociological Approaches, Berlin: Springer-Verlag, 10-25. 
